\title{
THE EU SANCTIONS OPERATION IN SYRIA: CONFLICT MANAGEMENT BY OTHER MEANS ${ }^{1}$
}

\author{
Clara Portela ${ }^{2}$ \\ Singapore Management University
}

\begin{abstract}
:
Since May 2011, the EU has crafted one of its most far reaching and sophisticated sanctions operations in support of the anti-regime protests against the current regime in Syria. The present article examines the measures wielded by the EU, its expected impact and its implications for the EU's relations with its global partners. While seriously undermined by the lack of support of Russia, the sanctions are having a noticeable economic impact. Yet, the choice of measures is ill-suited to stop the bloodshed. The sanctions have also served to (re)define partnerships with other powers, both in the Middle-East and globally.
\end{abstract}

Keywords: Syria, targeted sanctions, European Union, CFSP, Strategic Partnerships, Responsibility to Protect.

\section{Resumen:}

A partir de mayo de 2011 la Unión Europea ha llevado a cabo una de las operaciones más sofisticadas sobre sanciones en apoyo de las protestas contra el régimen político de Siria. El presente artículo examina las medidas autorizadas por la Unión Europea, su impacto esperado y las implicaciones para sus relaciones con sus socios globales. Aunque hayan quedado seriamente debilitadas por la falta de apoyo de Rusia, las sanciones están teniendo un impacto económico visible. No obstante, las medidas escogidas no son las más adecuadas para detener el derramamiento de sangre. Las sanciones han servido también para redefinir las asociaciones con otras potencias, tanto en Oriente Medio como a nivel global.

Palabras clave: Siria, sanciones específicas, La Unión Europea, PESC, Asociaciones Estratégicas, Responsabilidad de Proteger.

Copyright $\odot$ UNISCI, 2012.

Las opiniones expresadas en estos artículos son propias de sus autores, y no reflejan necesariamente la opinión de UNISCI. The views expressed in these articles are those of the authors, and do not necessarily reflect the views of UNISCI.

\footnotetext{
${ }^{1}$ This paper was first published as Egmont Security Policy Brief No. 38 in September 2012 by Egmont, Royal Institute of International Relations. Data correspond to late August 2012. The author thanks Thomas Renard, André Bank, Rosa Balfour and Dursun Peksen for their input.

${ }^{2}$ Dr Clara Portela is Assistant Professor of Political Science at Singapore Management University (Singapore). Her research focuses on the foreign policy of the European Union, in particular international sanctions. She is the author of European Union Sanctions and Foreign Policy (Routledge 2012) and the recipient of the 2011 THESEUS Prize for Promising Research on European Integration.
}

E-mail:

http://dx.doi.org/10.5209/rev_UNIS.2012.n30.4070 


\section{Introduction}

One year and a half after the beginning of the protests against the current regime in Syria, the European Union's (EU) response to the Arab Spring has taken some unprecedented traits. The popular uprisings in the Arab world have led the EU to employ an instrument it had been traditionally reluctant to use in this region: sanctions. They were imposed against targets in Tunisia, Egypt and Libya in the early days of the Arab Spring. However, they fulfilled different roles: In Tunisia and Egypt, where leaderships were unseated after only few weeks of protests, giving way to transitional governments, the EU froze the assets held in European accounts in order to prevent ousted leaders from accessing state funds. In Libya, sanctions were quickly followed by a multinational military operation under NATO command which precipitated the defeat of government forces. By contrast, in Syria neither have the protests succeeded in ousting President Bashar Al-Assad, nor has the use of force been seriously contemplated. The Syrian leadership consistently refuses to step down or to negotiate with opposition groups, opting instead for a strategy of repression which has been the subject of widespread international condemnation. Since the eruption of violence in March 2011, the situation has been characterised by stalemate, until protesters started making progress against government forces in July 2012. In the face of continued violence, the United Nations Security Council (UNSC) remains deadlocked: Russia has indicated its readiness to yield a veto against any proposal to intervene. A military operation to put an end to the crackdown on protesters remains unlikely for fear of a domino effect that could exacerbate conflicts in this volatile region. The UK along with the US and some of Syria's neighbours such as Saudi Arabia and Qatar has resorted to arming opposition forces. Yet, the EU is still far away from reaching an agreement on military intervention - even though calls in that direction proliferate among European politicians. In the absence of policy alternatives, sanctions currently constitute the core of the EU's response to the conflict in Syria. The EU first asked Al-Assad to negotiate with the opposition, then to cease repression, and as from August 2011, to leave office. $^{3}$ These demands were supported by sanctions imposed alongside those of the US, and tightened in reaction to successive crackdowns on civilians.

The sanctions against Syria are unprecedented. To begin with, the EU deployed the virtual entirety of measures in the sanctions toolbox within less than a year. In its past practice, it usually wielded an arms embargo and a visa ban on the leadership and their associates. The tightening of sanctions in subsequent rounds often consisted in lengthening the blacklist and applying an assets freeze to the featured individuals. While this process often took years, the sanctions against Syria have accumulated the whole set in just a few months. Most notably, they entail an energy embargo, namely a ban on the import of oil from Syria - a rare measure for the EU to adopt in the absence of a UNSC mandate given that the EU imports this oil to meet its own energy needs. Prior to the embargo, the EU's import of Syrian crude was worth over $€ 3$ billion a year, and went mostly to Italy and Germany. ${ }^{4}$ Finally, sanctions were agreed at the request of the League of Arab States (LAS), a regional organisation that had encouraged such measures against one of its members only once before in its history - against Iraq in the early 1990s.

\footnotetext{
${ }^{3}$ Balfour, R. (2012): "EU Conditionality after the Arab Spring", EIMed (Barcelona) Papers IEMed no. 16.

${ }^{4}$ Figures for 2010, at http://exporthelp.europa.eu.
} 


\section{A Whole Set in Less than a Year}

The declared objective of the EU is to increase pressure on the Assad regime to end repression, withdraw the Syrian army from besieged towns and cities, the implementation of democratic reforms and an inclusive national dialogue. The sanctions wielded against Syria encompass 17 sets of restrictive measures, according to the EU's own counting. ${ }^{5}$ The sanctions package comprises a set of very diverse measures which can be expected to affect the regime and Syrian society very differently. Also, these measures display different level of "targetedness", defined in terms of their capacity to discriminate between targets. A brief overview ${ }^{6}$ of the main prohibitions follows:

- A first set of sanctions targets the Syrian government: EU sanctions prohibit disbursements and assistance by the European Investment Bank (EIB) as well as new grants or loans by the member states. The EIB had some 17 project underway in Syria in 2011, and reportedly a portfolio worth $€ 1.3$ billion. ${ }^{7}$ In the same vein, measures are designed to ensure that private actors in Europe do not issue loans for those cooperation projects that have been interrupted by the EU - notably, the construction of power plants. The issuing of insurance to the Syrian government and the opening of new subsidiaries of Syrian banks in the EU are banned, as is the opening of new offices of European banks in Syria. The assets of the Syrian central bank in the EU are frozen and it is forbidden to trade public bonds to and from the Syrian government, public bodies and financial institutions.

- A second set of sanctions targets those individuals directly involved in the exercise of repression, with the intention of affecting them and their associates personally. They are prohibited from entering the territory of the EU, and the assets they hold in Europe are frozen. These individuals feature in a blacklist currently comprising 155 entries, while the blacklist of entities to which they are linked numbers 53. The freezing of assets and the visa ban on the leadership and their associates fulfils a double objective: cutting them off from financial assets so these cannot be used for repression and making the conduct of their business in Europe more difficult. Family members of the Syrian leadership are simultaneously heading state companies and entities associated with the regime - a personal connection that warrants their listing. In addition, they stigmatise blacklisted individuals and inconvenience them in a private capacity.

- A third set of sanctions is directed towards the repressive apparatus of the regime. Some measures concern the arms sector: the transfer of weapons and equipment that can be used for internal repression is banned. The arms embargo is supplemented by technical and financial assistance related to these items. The initial arms ban was broadened to encompass some dualuse items in the tightening that took place in April 2012. An innovative measure not covered by standard EU embargoes consists in banning the supply of software for the interception of internet and phone communications; in other words, the sort of equipment necessary for the security forces to locate opposition forces and monitor their activities. The latest reinforcement of the embargo consists in the decision to inspect vessels and aircraft suspected of transporting weapons to Syria via Europe, a measure along the lines of UNSC sanctions regimes against Iran and North Korea.

\footnotetext{
${ }^{5}$ Council of the European Union (2012): “The EU and Syria: Fact Sheet”, Press Release (20 August 2012).

${ }^{6}$ For the text of the legal instruments, consult http://eeas.europa.eu/cfsp/sanctions/docs/measures en.pdf, in particular Council Decisions 2011/782/CFSP, 2012/122/CFSP and 2012/206/CFSP.

${ }^{7}$ Norman, L. (2011): “EU set to broaden Syrian sanctions”, Wall Street Journal, 11 November 2011.
} 
The EU arms embargo is not bound to have any major effect: Syria's top weapons suppliers are Russia, Iran, Belarus and North Korea, while supplies from European countries stopped already in the early nineties. Russian arms exports to Syria have more than tripled in the period from 2008 to $2011^{8}$, and continue into 2012. Nevertheless, the mere prohibition of software can have some limited impact, as alternative suppliers can offer similar technology, but of lower efficacy.

- A fourth set of sanctions specifically targets the energy sector, with the intention of cutting off the government's sources of revenue, and thus weaken repression. These entail a ban on the import of oil and petroleum products from Syria, but also a prohibition on providing insurance to this sector, supplying technology for the oil and natural gas sector, as well as providing loans to enterprises engaged in the oil industry. The purchase or increase in participation in Syrian enterprises engaged in the oil sector is prohibited. The electricity sector is also affected: participation in the construction of new power plants for electricity generation, the provision of technical or financial assistance and the creation of joint ventures to that end is also banned. The ban on oil and petroleum products from Syria is the single most powerful measure in the package, given that fuels and mining products constitute over $89 \%$ of the EU's imports from Syria. ${ }^{9}$ The ban on insurance has serious economic implications, since oil shipments now have to be insured by authorities in the recipient states, which might not be prepared to bear the costs.

- A fifth category concerns trade restrictions. Measures affecting bilateral trade include a ban on cargo-only flights, and a ban on the export of certain goods: luxury products, gold, diamonds and precious metals. Aside from the oil embargo, the trade measures are modest. The EU merely imported some textiles and agricultural products from Syria, sectors representing respectively $4.8 \%$ and $2.7 \%$ of total imports from Syria. The restrictions affecting trade are geared towards preventing conspicuous upgrades in the limited trade flows that remain after the import of oil, which made up most bilateral trade. The ban on luxury goods, one of the most recent measures, is also directed against the elite. Overall, the bans affect imports are rather marginal. In 2011, Syria was the EU's $54^{\text {th }}$ trading partner, accounting for only $0.2 \%$ of its trade with the world. By contrast, the EU accounted for $21 \%$ of Syrian trade with the world ${ }^{10}$, and the export of crude oil to the EU represented $27.4 \%$ of total exports in 2010. Restrictions also concern the provision of financial support for trade: member states are not allowed to enter into long-term commitments, while short- and medium-term financial support for nationals and entities trading with Syria are discouraged. In spite of these restrictions, trade preferences per se have not been withdrawn - the procedure foreseen for the suspension of the Generalised System of Preferences (GSP) would take over a year, and the fear is that it would mostly affect small and medium enterprises unconnected to the regime.

- Finally, several EU member states such as Belgium, France, Italy, the Netherlands and Spain have closed their embassies in Damascus, a diplomatic sanction that does not qualify as an EU measure given that it was not jointly agreed by the European Council. Yet, the EU Delegation remains open.

\footnotetext{
${ }^{8}$ SIPRI Arms Transfers Database, at http://www.sipri.org/databases/armstransfers.

${ }^{9}$ Figures for 2011, at http://ec.europa.eu/trade/creating-opportunities/bilateral-relations/countries/syria/.

${ }^{10}$ Ibid.
} 


\subsection{But Can thev Work?}

What impact do these measures have - and do they stand a chance of succeeding in discouraging repression? EU officials have reportedly indicated that the sanctions package "seems to make the functioning of the government more difficult" and "causes significant anxiety and concern to the Syrian regime". ${ }^{11}$ In order to transform the arms embargo into an effective measure, it would need to be universalised and made mandatory by means of a UNSC Resolution - a step that the EU and the US have been promoting to no avail, most recently in July 2012. Certain measures can hardly be expected to instil a policy change in spite of the strong symbolism of the message they convey, such as the ban on luxury goods or the blacklisting of high-ranking officials. The trump card of the sanctions package is the oil embargo, given that most of the oil produced by Syria used to be sold to the EU. This constitutes the only measure, along with the restrictions in the banking sector, which is reportedly fulfilling its objective of depriving the regime of key revenue. ${ }^{12}$ According to the EIB, in 2011 growth was negative (estimated at $-2 \%$ ) due to the conflict and the international sanctions, and with the decrease in oil, tourism and tax revenues, the fiscal deficit is expected to increase to $11 \%$. $^{13}$ The GDP reportedly contracted by $3.4 \%$ during 2011 , according to the Economist Intelligence Unit. However, the prohibition on insurance and supply of spare parts for the oil and gas sector, which proved effective when applied on Libya by the US in the 1990s, needs years to display its results. One could presume that the trade-related measures are susceptible of affecting trade beyond the stipulated prohibitions by increasing the risk premium on economic engagement with Syria. In other words, European companies might be discouraged from conducting trade with Syria even in goods that are currently permitted for fear that what is now legitimate commerce might be banned in a subsequent tightening. However, such effects are hardly desirable: Firstly, because EU sanctions aspire to be targeted and should discriminate between those who are involved in government repression and those who are not; and secondly because they may interfere with the provisions for the numerous humanitarian exemptions that permeate EU sanctions legislation.

\section{Strategic Issue, Deceptive Partnerships}

If hitherto unable to halt the violence in Syria, the EU has nonetheless managed to take joint action and to position itself on this delicate issue vis-à-vis other regional and global powers. Significantly, the EU's sanctions package is in tune with the position of Syria's neighbours: the imposition of sanctions responded to a call by the Arab League, composed by a group of countries traditionally sceptical of the use of this policy tool. The suspension of Syrian membership by the Organisation of Islamic Co-operation, a body composed of 57 members, highlights the wide condemnation of the regime among Islamic countries (with the notable exception of Syria's ally: Iran). The position of the EU has a double, partly contradictory motivation. Part of the impulse behind the sanctions is to show support for the Arab uprisings, in an attempt to make up for its lack of determination during the first weeks of the Arab spring in early 2011. The self-avowed half-heartedness with which the EU had promoted democracy in the region until the popular revolts erupted constitutes an embarrassing background to the EU's attempts to profile itself as a supporter of the protest movement. This

\footnotetext{
${ }^{11}$ Mahony, H. (2012): "EU Ministers set to beef up Syria arms embargo", EUObserver, 20 July 2012.

${ }^{12}$ Landis, J. (2012): "The Syrian Uprising of 2011: Why the Assad Regime is likely to survive to 2013", Middle East Policy, vol. 19, no. 1, pp. 72-84.

13 "Financing operations in Syria", FEMIMP, at

http://www.eib.europa.eu/attachments/country/syria_2012_en.pdf.
} 
puts EU sanctions policy more in tune with its programmatic intention to promote democracy and human rights - a departure from its earlier practice in the Arab World, where it had exclusively wielded sanctions in support of anti-terrorism and non-proliferation goals. On the other hand, the EU is simultaneously aligning itself with regional powers which resist the spread of democracy in the Middle East, such as Qatar and especially Saudi Arabia.

The Syrian sanctions package has had the effect of aligning the EU and the US closely in an encouraging example of effective transatlantic collaboration: after some initial disagreements about the scope of the arms embargo, the measures agreed by the EU almost perfectly match those put in place by the US. This coincidence prevents a situation in which European companies can take over trade links previously entertained by US companies something that is now being done by non-Western operators. Also, the sanctions operation against Syria contributes to the US objective of containing Iran, who is the target of a parallel sanctions regime. Sanctions have been adopted by traditional partners of the EU, such as Switzerland. Even Turkey, a key regional power directly neighbouring on Syria, has imposed sanctions that go beyond "any previous Turkish sanctions against any neighbour". ${ }^{14}$ Turkey originally wielded an arms embargo, assets freezes, and diplomatic sanctions, but later added trade sanctions such as raising taxes on Syrian goods and closing border crossings for trade.

The sanctions have pitted the EU against Russia, one of its "strategic partners", which continues to threaten a veto in the UNSC. Supporting the sanctions would contradict significant traits of its foreign policy. It would entail ceasing support for the last remaining ally inherited from the Cold War era in a region where it is almost deprived of influence. The strategic importance of Syria to Russia does not only emanate from the lucrative weapons deals it secures, but also from being the host of Russia's only maritime base in the Mediterranean. Losing Syria, Russia's last stronghold in the Middle East, would be a major psychological and reputational setback. Furthermore, Moscow has a principled reluctance to be seen as supporting "regime change" against a long-standing associate, especially as Russia's allies elsewhere expect to be reassured of unwavering Russian support in the face of Western pressure.

Other powers occupy a middle position somewhere between the transatlantic and the Russian stance. The stance of other BRICS countries has become evident thanks to their membership of the UNSC in the period 2011/12. Brazil, South Africa and India, who served in the UNSC as the Syrian crisis unfolded, abstained from a draft resolution condemning Syrian repression in October 2011. Last year's experience in Libya showed how a UNSC mandate authorising force in application of the doctrine of the "Responsibility to Protect" could be used by external powers to launch a fully-fledged war. This has tempered the BRICS' appetite to endorse mandates along similar lines. By holding back from a UNSC resolution, BRICS are siding with each other in resisting new action cementing the admissibility of intervention to address internal repression. Nevertheless, an evolution is visible. Having grown increasingly condemnatory of Syrian repression, India and South Africa supported a resolution last February similar to the failed draft of October 2011, which was eventually vetoed by Russia and China. In turn, the shift in India's and South Africa's votes has apparently compelled veto-bearing countries to somewhat distance themselves from Damascus. ${ }^{15}$ While China has consistently vetoed UN resolutions alongside Russia, its condemnation of the Syrian government has become harsher. If Moscow was to relax its opposition, Beijing would likely be reluctant to wield its veto, especially given that its

\footnotetext{
${ }^{14}$ Walker, J. (2012): “Turkey’s Syrian Dilemma”, EPC Commentary (9 July 2012).

${ }^{15}$ Traub, J. (2012): “Will the good BRICS please stand up?”, Foreign Policy (9 March 2012).
} 
interests are not directly involved. The recent proliferation crises in Iran and North Korea have seen China agreeing to sanctions, privileging regional stability and its image as a "responsible power" over its traditional adherence to the principle of non-intervention. ${ }^{16}$

The BRICS positioning around the Syrian issue suggests that the EU's strategic partnerships have not been of much use in winning the support of emerging powers. Russia, a strategic partner, constitutes the main obstacle hindering sanctions, while Turkey, both a key regional power and a NATO ally which does not enjoy such status, has resolutely aligned itself with the EU and the US. Disappointingly, the communiqué of the most recent EU-China High-Level strategic dialogue does contain one single reference to Syria. ${ }^{17}$ In sum, the reaction of regional and global powers to crises like the one in Syria remains mostly driven by interests alien to the policy preferences of the EU, whose influence through its strategic partnerships remains hardly noticeable - an outcome that puts into question the very raison d'être of these partnerships.

\section{Syria and the Future of EU Sanctions Policy}

The analysis that the combined EU and US sanctions against Syria are causing considerable damage to the economy is unusually consensual - even though, at the time of writing, its impact on the power balance in Syria and on the course of the crisis is difficult to ascertain. The irony about EU energy sanctions is that only extremely pressing situations such as violent government repression entailing growing civilian casualties garner sufficient support for the swift adoption of strong measures like energy bans or embargoes on oil extraction equipment. And yet, because these measures require some time to produce sufficient damage to encourage concessions, they are ill-suited to address situations requiring an urgent fix such as the current crisis in Syria.

Which future does the current response to Syria herald for EU sanctions policy? The sanctions package against Syria demonstrates that the EU is able to surmount the main structural deficiency of its sanctions, namely the weakness of its measures in terms of the little disutility they cause. ${ }^{18}$ Notably, the package includes import and export bans damaging some European business interests, a feature it shares with the Iran sanctions. The reluctance to affect trade constituted so far a "red line" that had hardly ever been crossed in the absence of a UNSC mandate, with the exception of the special case of the arms trade. Moreover, trade bans such as the prohibition to import gems from Myanmar were bound to have only negligible economic impact for European companies. By contrast, we are now witnessing how security interests trump commercial advantage. Also, the speed with which the whole package was agreed was remarkable for EU standards: in the past, sanctions regimes were tightened very slowly, with upgrades often consisting in the mere lengthening of existing blacklists. For an entity believed to be too unwieldy to frame a credible sanctions policy only a few years ago, the EU's crafting of sanctions has been remarkably speedy and broad particularly in view of the block's growing membership and the persisting unanimity rule under which the CFSP operates.

\footnotetext{
${ }^{16}$ Oertel, J. (2011): "China und das Sanktionsregime der Vereinten Nationen”, SWPAktuell no. 23 (April 2011).

${ }^{17}$ European Union (2012): "Joint Press release after the $3^{\text {rd }}$ EU-China High-level Strategic Dialogue", A318/12, Brussels (10 July 2012).

${ }^{18}$ Portela, C. (2010): European Union Sanctions and Foreign Policy, Routledge, London.
} 
Sadly, the fact that the EU incorporates selective trade bans in its sanctions has distressing implications. Firstly, it signifies a move away from the narrowly targeted sanctions that impeccably characterised EU sanctions policy. Because assets freeze and visa bans are based on a blacklist, they single out those individuals and entities held to bear responsibility for misbehaviour. By contrast, selective embargoes affect entire sectors and are those more likely to disadvantage individuals bearing no responsibility for the condemned policies. Finally, while the blacklists did not pose any major obstacle to bilateral trade with targets, the inclusion of trade restrictions will do little to increase the popularity of a sanctions regime widely regarded as a poor substitute for an unlikely military intervention. 